\title{
Day time variations of zooplankton species composition: observations from the wetlands of Assam, India
}

\author{
Variações diurnas da composição das espécies de zooplâncton: observações das áreas \\ úmidas de Assam, Índia
}

Papia $\operatorname{Das}^{1}$ (D), Sulata $\operatorname{Kar}^{1}$ (D), Uma Das ${ }^{1}$ (D), Maibam Bimola ${ }^{2}$, Devashish $\operatorname{Kar}^{1}$ and Gautam Aditya ${ }^{3 *}$

${ }^{1}$ Department of Life Science and Bioinformatics, Assam University, Silchar 788011, India

${ }^{2}$ Department of Zoology, Chanambam Ibomcha College, Bishnupur 795126, Manipur, India

${ }^{3}$ Department of Zoology, University of Calcutta, 35 Ballygunge Circular Road, Kolkata 700019, India

*e-mail: gautamaditya2001@gmail.com

Cite as: Das, P., et al. Day time variations of zooplankton species composition: observations from the wetlands of Assam, India. Acta LimnologicaBrasiliensia, 2020, vol. 32, e10.

Abstract: Aim: An attempt to justify the variations in the species composition of zooplankton over the day time period was made using the freshwater lakes of Assam, India, as a model study area Methods: The water bodies were sampled using a conical plankton net five times between 6 am and $6 \mathrm{pm}$ in a day during July 2014. Apart from diversity analysis (SHE analysis), discriminant function analysis and a regression tree were built to justify the variations in the zooplankton species composition in the different time periods in a day. Results: Repeated sampling during day time indicated the presence of 34 zooplankton species with varied composition over the different time periods. The species richness and abundance of Copepoda, Cladocera and Rotifer differed significantly revealed through the ANOVA (for rotifers $-\mathrm{F}_{4,170}=28.792$; for cladocerans $-\mathrm{F}_{4,170}=16.343$; for copepods $-\mathrm{F}_{4,170}=9.027$ ). Apparently, the rotifer and copepod abundance was prominent during the early $(6 \mathrm{am})$ and late time $(6 \mathrm{pm})$ periods of a day while the cladoceran abundance was significant during the middle time periods (12 noon to $3 \mathrm{pm}$ ) of a day. Variations in the relative abundance of the zooplankton species within a day were sufficient to discriminate the time periods significantly. The regression tree indicated the rotifer abundance (node 1), followed by the cladoceran and the copepod abundances (node 2). The nodes representing cladocerans explained $30.86 \%$ of the data while the copepod explained $69.14 \%$ data as a split from the rotifer groups. Conclusions: A correspondence of high and low abundances of rotifers and cladocerans was characteristic of the species composition of the zooplankton in the study area. The variations in the species composition suggests that the zooplankton exhibits movements either in horizontal or vertical directions induced by physical and/or biological factors. Further studies may be adopted to elucidate the effects of the predators and environmental variables that shape the community of the zooplankton in shallow tropical lakes.

Keywords:day time variations; zooplankton; Copepoda; Rotifera; Cladocera.

Resumo: Objetivo: Um esforço para esclarecer as variações na composição de espécies de zooplâncton ao longo do dia foi feita utilizando lagos de água doce do Nordeste da Índia, em Assam, como área de estudo modelo. Métodos: Os corpos de água foram amostrados com uma rede de plâncton cônica cinco vezes, entre $6 \mathrm{~h}$ e $18 \mathrm{~h}$, em um dia de julho de 2014. Além da análise de diversidade (análise RHU), uma análise de função discriminante e uma árvore de regressão foram elaboradas para 
esclarecer as variaçôes na composição das espécies de zooplâncton em diferentes períodos do dia. Resultados: Amostras repetidas durante o dia indicaram a presença de 34 espécies de zooplâncton, com composição variada, ao longo dos diferentes períodos de tempo. A riqueza e abundância de espécies de copépodes, cladóceros e rotíferos diferiram significativamente, como demonstrado pela ANOVA (para rotíferos - F4, 170 = 28.792; para cladóceros - F4, 170 = 16.343; para copépodes - F4, $170=9.027)$. A abundância de rotíferos e copépodes foi maior nos períodos inicial $(6 \mathrm{~h})$ e final $(18 \mathrm{~h})$ do dia, enquanto a abundância de cladóceros foi significativa nos períodos intermediários (12h às $15 \mathrm{~h}$ ). As variaçóes na abundância relativa das espécies de zooplâncton durante o dia foram suficientes para discriminar os períodos de tempo significativamente. A árvore de regressão indicou a abundância de rotíferos (nó 1 ), seguida pelas abundâncias de cladóceros e copépodes (nó 2). Os nós representando os cladóceros explicaram $30,86 \%$ dos dados, enquanto o de copépodos explicou $69,14 \%$ dos dados como uma divisão dos grupos de rotíferos. Conclusóes: Uma correspondência de altas e baixas abundâncias de rotíferos e cladóceros foi uma característica da composição de espécies do zooplâncton na área de estudo. As variações na composição das espécies sugerem que o zooplâncton exibe movimentos tanto horizontais como verticais, induzidos por fatores físicos e/ou biológicos. Estudos adicionais são necessários para elucidar os efeitos de predadores e variáveis ambientais que moldam a comunidade do zooplâncton em lagos tropicais rasos.

Palavras-chave: variaçóes diurnas; zooplâncton; Copepoda; Rotifera; Cladocera.

\section{Introduction}

The spatial distribution of freshwater zooplankton varies with the time in a day, owing to the movements in the vertical or the horizontal plane (Doulka \& Kehayias 2008). Observations suggest that this process is repeated over time and qualify as a diel periodicity or rhythm. As a consequence of the phenomenal movement of zooplankton, the species composition varies at a particular space, with consistency of repeated patterns in short as well as long time scales (Burns \& Mitchell 1980). Several hypotheses have been suggested to explain the diel variations in the composition of the zooplankton species in lakes and ponds (Burks et al., 2002; Hays, 2003; Perticarrari et al., 2003). Predator induced shifts in the spatial occupancy of the zooplankton species is considered as an important reason for the diel movement (George \& Fernando, 1970; Braghin et al., 2016). Water circulation induced changes in the micronutrient availability and environmental factors like anoxia are also considered as probable reason for the movement of the zooplankton in the freshwater bodies (George \& Heaney 1978; Lampert 2005). The regulatory factors influencing the movements of the zooplankton vary with the dimensions of the freshwater bodies (Siegfried et al., 1996; Miron et al., 2014). In deep lakes, the vertical movements in course of day and season are more profound, while in shallow lakes the horizontal movements are more prominent (Burks et al., 2002; Altindag et al., 2007; Rabindranath et al., 2010). Nonetheless, irrespective of the spatial dimension and the causative factors, the movements of the zooplanktons within the space are observed for almost all lentic systems, reflecting the mechanism to be an adaptive feature of the zooplankton.

Movement of the zooplankton within a fixed space may be rhythmic following a daily light cycle, the nutrient availability, predation pressure or a combination of both, as well as hypolimnetic anoxia caused by lake stratification, temperature which may lead to corresponding changes in the species composition (Burks et al., 2002; Arcifa et al., 2013). The pattern of changes in the zooplankton species composition can induce correlated changes in the macroinvertebrate predator and fish species composition in the same space. The coupled changes in the species composition of the zooplankton and the predators in space within short time scale bear implications in the dynamic nature of community structure and species interactions. A shift in the spatial occupancy of the prey and predator is also influenced by the habitat heterogeneity caused by the macrophytes, which is more pronounced for the littoral zone than in the pelagic zone of lakes and ponds (Evans, 1997). The changes in the species composition and the assemblage pattern can be traced through repeated estimates of the zooplankton against a fixed space. Although, using longer time scale, the diel variations of zooplankton can be assessed on a seasonal basis, the short time scale observations provide the general observations on the pattern of changes particularly for the smaller water bodies (Burns \& Mitchell, 1980; Dutta et al., 2009).

In Indian context, studies on the zooplankton diversity of rivers, lakes and ponds have been carried out to support (Sharma et al., 2017) the information on the productivity and monitoring the environmental condition. Exploration of 
the species composition of zooplankton enabled aquaculture management for the lakes and ponds in different regions within India. However, little effort has been made to portray the diel movements leading to changes in the zooplankton species composition over shorter-time scale. Considering the relevance of the zooplankton in environmental monitoring and aquaculture, the present study was aimed at characterizing the zooplankton assemblages of selected lakes and ponds of Assam, a representative state of Northeast India. Empirical evidences indicate considerable diversity of zooplankton, particularly cladocerans and rotifers in the floodplain lakes of the concerned geographical area, though the diel variations of the zooplankton assemblages remain to be characterized yet. Many of the shallow water lakes and ponds in Assam and adjacent states are exploited both for capture fisheries and aquaculture resources, representing the significance of these water bodies for food security and livelihood. Characterizing the zooplankton species assemblages over the short time period will highlight the pattern of the community structure and provide qualitative information on the use of the zooplankton in environmental monitoring and aquaculture management. The results will be useful in understanding the spatial scale abundance of the different groups of zooplankton and predict the possible movements of the consumer taxa of the concerned community. The diel pattern may provide insights of the spatial distribution and prospective feeding behavior of the fish and other macroinvertebrates of commercial importance.

\section{Material and Methods}

The study was conducted in the month of July 2014 coinciding with the monsoon of the geographical area concerned. The study sites are five different freshwater wetlands namely MahisaBeel, Mandir Dighi, RamnagarAnua, SrikonaBeel and TapangHaor in the state of Assam, India. MahisaBeel is a freshwater wetland in Cachar district, Assam (Figure 1). An overview of the wetlands is provided in Table 1. The collection of plankton samples was

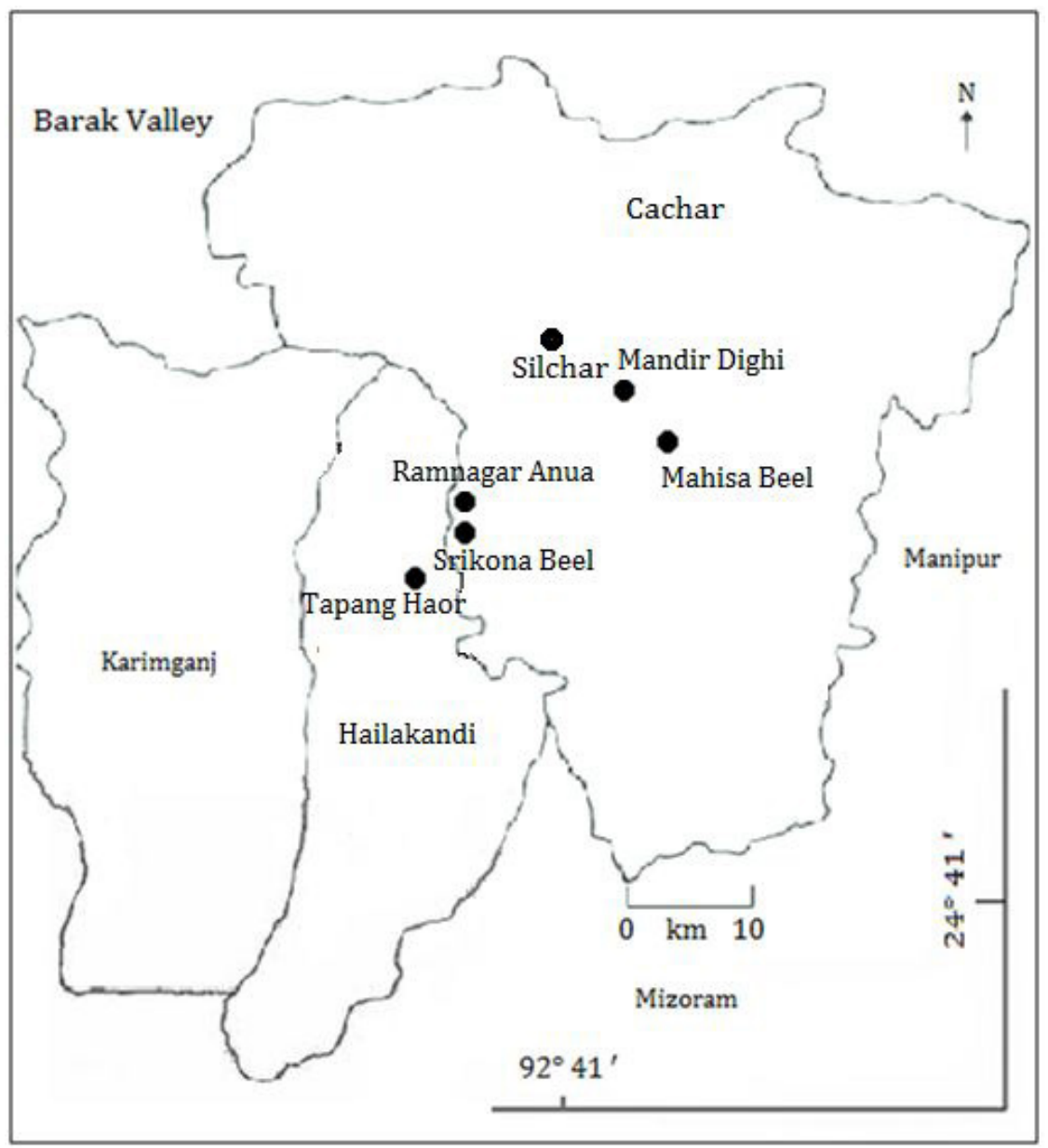

Figure 1. Map of Barak valley, Assam, India, showing the sampling sites. 


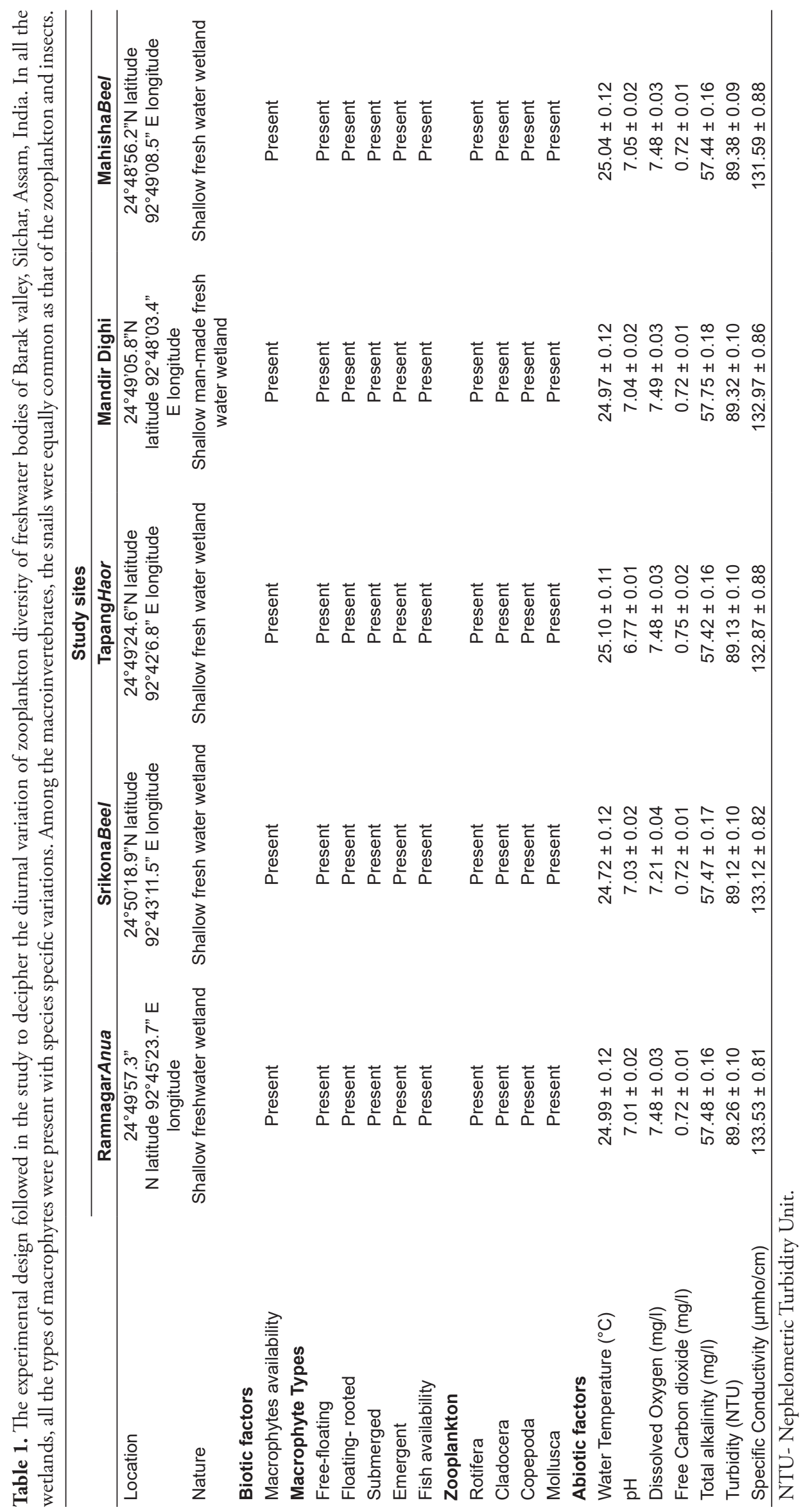


done by using $125 \mu \mathrm{m}$ mesh size conical plankton net having a diameter of $30 \mathrm{~cm}$. The mesh size was estimated by following the repeated count of the number of holes found in a linear inch of the sampling net. A portion of sampling net was placed under binocular microscope and the number of the holes per inch was counted followed by calculation of the mesh size in terms of microns which was $125 \mu \mathrm{m}$ (Nash, 1997; Riccardi, 2010; Mack et al., 2012; Pansera et al., 2014).

Sampling was performed for collection of zooplankton in the five different sites at fixed time intervals viz., 6:00 am, 9:00 am, 12 noon, 3:00 pm and 6:00 pm, for a month of July 2014 following the standard methods (Edmondson, 1959; Michael and Sharma, 1988; APHA, 2005). In each sampling instance, the plankton net fitted with a long nylon thread was thrown within a range of $1 \mathrm{~m}^{2}$ area and pulled horizontally along an average depth of $20 \mathrm{~cm}$. Owing to the shallow nature of the water bodies, vertical depth could not be considered for sampling. At least six pulls were considered to include the heterogeneity of the zooplankton in the samples. The collected zooplankton were filtered and subsequently transferred into sample tube (Tarsons* $100 \mathrm{~mL}$ ) and fixed in Lugol's solution for further study. After collection and fixation, the zooplankton species in the samples were estimated using the Sedgwick-Rafter counting chamber under a light microscope with required magnification (X 10 initially, followed by X 40) for identification (Edmondson, 1959; Battish, 1992; Sharma \& Sharma, 2008). Following identification and record of the data from five different shallow water bodies on seven different days within the month of July 2014 , the data were subjected to statistical analyses to highlight the species specific and group specific relative abundance of the zooplankton.

\subsection{Data analysis}

The data on the different zooplankton species collected during the specific time period were subjected to diversity index analysis to portray the differences in the richness and abundance of the species over the time period in a day (Legendre $\&$ Legendre, 1998; Zar, 1999; De'ath \& Fabricius 2000; Pepin et al., 2015). The SHE (S - species richness, $\mathrm{H}$ - Shannon-Weiner diversity index and E - Evenness) analysis was employed to highlight the differences in the richness and abundance of the different species of zooplankton using the evenness parameter and the number of species present in the samples concerned. The time dependent variations in the relative abundance of the three groups, rotifers, cladocerans and copepods were evaluated by ANOVA. Using discriminant function analysis (DA) (Manly, 1994), the variations in the time periods of a day were portrayed with reference to the zooplankton species as explanatory variables. The purpose of DA was to portray the time periods of a day as a specific representative of the zooplankton species assemblages which is expected to differ as a consequence of the movement of different species comprising the assemblages. Further, the contribution of the three groups in the species composition of the zooplankton in the different time period was portrayed through the regression tree analysis (De'ath \& Fabricius 2000) following classification and regression tree algorithm (Addinsoft, 2010). The analysis was used to highlight the groups in terms of a rank based on the importance as contributor in the particular time period. Earlier application of the regression tree was made to highlight diversity the abiotic factors in explaining the species of the zooplankton in the wetlands of Upper Paraná River floodplain (Braghin et al., 2016). In the present instance the decision tree was constructed based on the chi-square automatic interaction detection analysis. In Chi-square automatic interaction detector (CHAID) analysis, the relationships between the dependent and the explanatory variables are portrayed as nodes with the splitting based on certain algorithm reflecting the rank order of importance of the explanatory variables (zooplankton groups) on the zooplankton composition in the different time periods. Thus the relative abundance of the different zooplankton groups and their contribution to the total abundance in the different time periods are being portrayed in the regression tree. Since the response variable in the present instance was categorical (time period), a chi-square test was applied to assess the least significant difference with respect to the dependent variable among each pair of predictor categories (zooplankton groups) and Bonferroni adjusted p-value was used. In the present instance the total dataset on the relative abundance of zooplankton at different time interval were split and separated at each hierarchical node and the relative contribution to the different time periods are represented through a bar diagram. The application of the regression tree was carried out to extend the observations of the discriminant function analysis (DA), such that the relative variations of the three groups of zooplankton on the total abundance in the different time periods can be portrayed. 
In order to deduce the variations of the groups of zooplankton in terms of the five time periods of a day, a generalized linear model (GLM) was assumed with the sites and time as explanatory variables. Assuming GLM, the data on the relative abundance of the three different groups, Rotifera, Cladocera, and Copepoda were subjected to regression following binomial GLM with logit link using the sites and specific time periods as predictors. The response variable was considered to be the proportion of each group, which was assumed to follow binomial $(\mathrm{n}, \mathrm{p})$ distribution with $\mathrm{n}$ observations (samples in each time period of observation) for each combination of the explanatory variables (Sites and time period). The probability parameter $\mathrm{p}$ is here a linear combination of the explanatory variables. In the present analysis, the parameters were estimated through maximum likelihood with logit link, using the software XLSTAT (ADDINSOFT, 2010). A Chi-square value was used to deduce the significance of the estimated parameters of the model.

\section{Results}

In course of repeated sampling during the study period a total of 34 species of zooplankton were observed, with highest representation of Rotifera (17 species), followed by Cladocera (13 species and Copepoda (4 species). The relative abundance of the representative species varied with the time period, with similar patterns being exhibited by the rotifers, the cladocerans and copepods (Table 2), in terms of the relative abundance in the time periods. Many of the species remained absent in the morning hours (6 am), though these were present in the later time periods. For instance, among the Rotifera, the Colurella uncinata was absent in 6 am and 3 pm but present in other time interval of the day, Rotaria neptunia was absent in 6 and 9 am but present in other time interval of the day, Pompholyx sulcata and Polyarthra vulgaris were absent in $6 \mathrm{am}$, $12 \mathrm{pm} 3 \mathrm{pm}$ and $6 \mathrm{pm}$ but present in 9 am of the day, Plationus patulus, was absent in 6 am and $12 \mathrm{pm}$ whereas it was present in remaining time interval of the day, Sinantherina sp., was absent

Table 2. Relative abundance of different zooplankton at different time period of a day observed in five different sites in Silchar, Assam, India ( a through c, the different groups of zooplankton).

\begin{tabular}{|c|c|c|c|c|c|c|}
\hline & \multirow{2}{*}{ Species } & \multicolumn{5}{|c|}{ Time scale of 24 hours } \\
\hline & & 6 & 9 & 12 & 15 & 18 \\
\hline (a) & \multicolumn{6}{|c|}{ Rotifera } \\
\hline 1 & BRA & $4.9 \pm 0.7$ & $7.3 \pm 0.8$ & $10.4 \pm 1.6$ & $8.7 \pm 1.0$ & $4.1 \pm 0.5$ \\
\hline 2 & KER & $0.8 \pm 0.2$ & $1.0 \pm 0.3$ & $2.8 \pm 0.5$ & $1.6 \pm 0.3$ & $0.6 \pm 0.2$ \\
\hline 3 & CEP & $0.1 \pm 0.1$ & $0.3 \pm 0.1$ & $1.0 \pm 0.3$ & $0.2 \pm 0.1$ & $0.3 \pm 0.2$ \\
\hline 4 & FIL & $0.1 \pm 0.0$ & $0.2 \pm 0.1$ & $0.3 \pm 0.1$ & $0.8 \pm 0.3$ & 0 \\
\hline 5 & LEC & $0.9 \pm 0.2$ & $1.8 \pm 0.5$ & $2.8 \pm 0.5$ & $3.1 \pm 0.4$ & $1.4 \pm 0.3$ \\
\hline 6 & TRI & $0.8 \pm 0.3$ & $1.6 \pm 0.4$ & $4.9 \pm 0.8$ & $3.5 \pm 0.4$ & $1.5 \pm 0.4$ \\
\hline 7 & ANU & $2.2 \pm 0.5$ & $1.8 \pm 0.4$ & $4.9 \pm 0.5$ & $3.1 \pm 0.5$ & $1.9 \pm 0.4$ \\
\hline 8 & LEP & $0.1 \pm 0.1$ & $2.0 \pm 0.4$ & $1.1 \pm 0.3$ & $1.3 \pm 0.4$ & $0.9 \pm 0.3$ \\
\hline 9 & ASC & $4.9 \pm 0.7$ & $7.4 \pm 1.0$ & $11.7 \pm 1.2$ & $6.8 \pm 0.7$ & $4.1 \pm 0.7$ \\
\hline 10 & ASP & $0.6 \pm 0.3$ & $4.5 \pm 0.8$ & $4.3 \pm 0.8$ & $4.3 \pm 0.8$ & $1.8 \pm 0.4$ \\
\hline 11 & TES & $1.1 \pm 0.4$ & $3.3 \pm 0.7$ & $5.7 \pm 0.7$ & $3.2 \pm 0.5$ & $1.6 \pm 0.4$ \\
\hline 12 & COL & 0 & $0.1 \pm 0.1$ & $0.7 \pm 0.2$ & 0 & $0.3 \pm 0.1$ \\
\hline 13 & ROT & 0 & 0 & $0.1 \pm 0.04$ & $0.1 \pm 0.05$ & $0.1 \pm 0.1$ \\
\hline 14 & POM & 0 & 0 & $0.2 \pm 0.1$ & 0 & 0 \\
\hline 15 & POL & 0 & $0.1 \pm 0.1$ & 0 & 0 & 0 \\
\hline 16 & PLA & 0 & $0.3 \pm 0.1$ & 0 & $0.1 \pm 0.1$ & $0.1 \pm 0.1$ \\
\hline 17 & SIN & 0 & 0 & 0 & $0.1 \pm 0.1$ & 0 \\
\hline
\end{tabular}

BRA- Brachionus sp., KER- Keratella sp., CEP-Cephalodella gibba, FIL- Filinia camasecla, LEC- Lecane sp., TRI- Trichocerca capucina, ANU-Anuraeopsis fissa, LEP-Lepadella sp., ASC - Ascomorpha ovalis, ASP-Asplanchna brightwelli, TES- Testudinella sp., COL- Colurella uncinata, ROT-Rotaria neptunia, POM- Pompholyx sulcata, POL- Polyarthra vulgaris, PLA- Plationus patulus, SIN- Sinantherina sp., CHY-Chydorus reticulatus, DIA-Diaphanosoma sarsi, ALO-Alona quadrangularis, BOSP-Bosminopsis deitersi, BOS-Bosmina longirostris, CER-Ceriodaphnia reticulata, MAC- Macrothrix sp., MOI- Moina micrura, MOID- Moinodaphnia macleayi, SID- Sida crystallina, SCA- Scapholeberis kingi, ALON- Alonella sp., SIM- Simocephalus sp., NEO- Neodiaptomus schmackeri, MES- Mesocyclops leuckarti, HEL- Heliodiaptomus contortus, THE- Thermocyclops crassus 
Table 2. Continued...

\begin{tabular}{|c|c|c|c|c|c|c|}
\hline & \multirow{2}{*}{ Species } & \multicolumn{5}{|c|}{ Time scale of 24 hours } \\
\hline & & 6 & 9 & 12 & 15 & 18 \\
\hline (b) & \multicolumn{6}{|c|}{ Cladocera } \\
\hline 18 & $\mathrm{CHY}$ & $1.8 \pm 0.4$ & $5.4 \pm 1$ & $6.1 \pm 0.8$ & $4.3 \pm 0.8$ & $3.0 \pm 0.5$ \\
\hline 19 & DIA & $1.3 \pm 0.4$ & $5.1 \pm 0.8$ & $5.9 \pm 1.1$ & $7.0 \pm 1.4$ & $3.5 \pm 0.6$ \\
\hline 20 & ALO & $0.1 \pm 0.1$ & 0 & $0.2 \pm 0.1$ & $0.1 \pm 0.1$ & 0 \\
\hline 21 & BOSP & $4.8 \pm 1.1$ & $3.0 \pm 0.7$ & $6.5 \pm 0.9$ & $5.0 \pm 0.8$ & $4.4 \pm 1.2$ \\
\hline 22 & BOS & $2.5 \pm 0.6$ & $3.7 \pm 0.9$ & $6.5 \pm 1.5$ & $6.3 \pm 1.6$ & $2.2 \pm 0.7$ \\
\hline 23 & CER & $1 \pm 0.3$ & $2.2 \pm 0.5$ & $2.5 \pm 0.7$ & $3.7 \pm 0.6$ & $0.8 \pm 0.3$ \\
\hline 24 & MAC & $0.6 \pm 0.2$ & $0.4 \pm 0.2$ & $1.3 \pm 0.3$ & $2.0 \pm 0.5$ & $0.5 \pm 0.2$ \\
\hline 25 & MOI & $2.8 \pm 0.5$ & $3.4 \pm 0.6$ & $6.6 \pm 0.7$ & $6.9 \pm 0.7$ & $3.5 \pm 0.8$ \\
\hline 26 & MOID & 0 & $0.2 \pm 0.2$ & 0 & 0 & 0 \\
\hline 27 & SID & 0 & $1.9 \pm 0.5$ & $2.0 \pm 0.5$ & $2.1 \pm 0.6$ & $1.2 \pm 0.4$ \\
\hline 28 & SCA & $0.4 \pm 0.2$ & $0.8 \pm 0.3$ & $1.2 \pm 0.4$ & $1.4 \pm 0.5$ & $0.5 \pm 0.2$ \\
\hline 29 & ALON & $0.1 \pm 0.1$ & $0.1 \pm 0.1$ & 0 & 0 & $0.1 \pm 0.1$ \\
\hline 30 & SIM & $0.1 \pm 0.1$ & 0 & $0.1 \pm 0.1$ & $0.2 \pm 0.1$ & 0 \\
\hline (c) & \multicolumn{6}{|c|}{ Copepoda } \\
\hline 31 & NEO & $2.2 \pm 0.6$ & $4.6 \pm 1.2$ & $9.5 \pm 2.1$ & $6.5 \pm 1.3$ & $4.3 \pm 1$ \\
\hline 32 & MES & $7 \pm 0.6$ & $13.6 \pm 1.6$ & $11.8 \pm 1.2$ & $13.3 \pm 0.8$ & $9.1 \pm 0.7$ \\
\hline 33 & HEL & $0.8 \pm 0.3$ & $2.6 \pm 0.7$ & $4.5 \pm 0.9$ & $4.1 \pm 0.7$ & $1.8 \pm 0.4$ \\
\hline 34 & THE & $1.8 \pm 0.4$ & $1.6 \pm 0.4$ & $3.7 \pm 0.8$ & $2.5 \pm 0.4$ & $2.0 \pm 0.4$ \\
\hline
\end{tabular}

BRA- Brachionus sp., KER- Keratella sp., CEP-Cephalodella gibba, FIL- Filinia camasecla, LEC- Lecane sp., TRI- Trichocerca capucina, ANU-Anuraeopsis fissa, LEP-Lepadella sp., ASC - Ascomorpha ovalis, ASP-Asplanchna brightwelli, TES- Testudinella sp., COL- Colurella uncinata, ROT-Rotaria neptunia, POM- Pompholyx sulcata, POL- Polyarthra vulgaris, PLA- Plationus patulus, SIN- Sinantherina sp., CHY-Chydorus reticulatus, DIA-Diaphanosoma sarsi, ALO-Alona quadrangularis, BOSP-Bosminopsis deitersi, BOS-Bosmina longirostris, CER-Ceriodaphnia reticulata, MAC- Macrothrix sp., MOI- Moina micrura, MOID- Moinodaphnia macleayi, SID-Sida crystallina, SCA-Scapholeberis kingi, ALON-Alonella sp., SIM- Simocephalus sp., NEO- Neodiaptomus schmackeri, MES-Mesocyclops leuckarti, HEL-Heliodiaptomus contortus, THE- Thermocyclops crassus

in the time period of $6 \mathrm{am}, 9 \mathrm{am}, 12 \mathrm{pm}, 6 \mathrm{pm}$ and but was present in $3 \mathrm{pm}$ time period, on the other hand among cladocera Alona quadrangularis was absent in $9 \mathrm{am}$ and $6 \mathrm{pm}$ but present in 6am, $12 \mathrm{pm}$ and $3 \mathrm{pm}$ of the day, the Moinodaphnia macleayi was absent in $6 \mathrm{am}, 12 \mathrm{pm}, 3 \mathrm{pm}$ and $6 \mathrm{pm}$ but it was only present in 9 am of the day, whereas Sida sp. was present all the time interval of the day except $6 \mathrm{am}$, Allonella sp. was absent in 12 and $3 \mathrm{pm}$ of the day and the Simocephalus sp. was absent in 9 am and $6 \mathrm{pm}$ of the day but present in remaining interval of the day. Application of the data on the species diversity analysis (SHE analysis) reflected the variations in the richness, evenness and relative abundance pattern characteristic of the five different time periods (Figure 2). The time dependent variations in the rotifers, cladocerans and the copepods were significantly different as revealed through the ANOVA (for rotifers $-\mathrm{F}_{4,170}=28.792$; for cladocerans $-\mathrm{F}_{4,170}=16.343$; for copepods $\left.\mathrm{F}_{4,170}=9.027\right)$. The ratio of the crustacean to rotifer zooplankton was $2.143 \pm 0.153$ (range $0-15.67$ ), and the ratio of the cladoceran to copepod zooplankton was $1.577 \pm 0.098$ (range $0-8.143$ ) comparable over the different time period and did not show significant variation against time (Figure 3). Using the differences in the relative abundance of the constituent zooplankton species, the five different time periods of a day could be characterized through the discriminant function analysis (Figure 4).

The results indicate that the Fisher's distance between the time period pairs were significant and the corresponding standardized canonical discriminant functions indicate the differential contributions of the zooplankton species. The ordination of the different species of zooplankton varied significantly as shown in biplot (Fig 4), as well as the different time periods of the sampling in a day. As shown in the regression tree, the hierarchical differences in the contribution of the rotifers, cladocerans and copepods in the relative abundance of the zooplankton in the different time scale was significant. The tree indicates the rotifer abundance (node 1), followed by the cladoceran and the copepod abundances (node 2) could explain the 

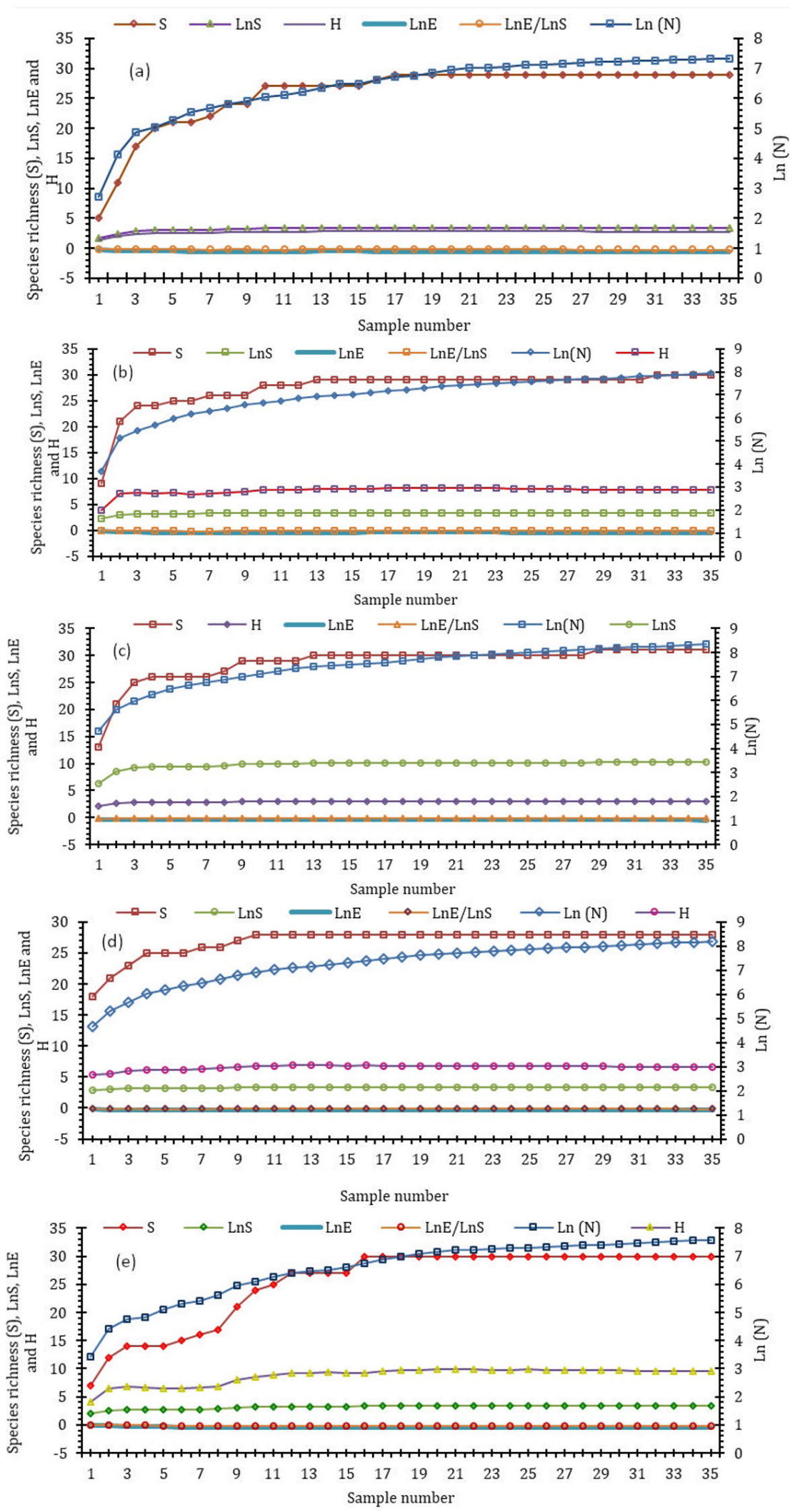

Figure 2. The SHE analysis (diversity analysis $\mathrm{S}$ - Species richness, H - Shannon - Weiner diversity index, E - Evenness component of Shannon-Weiner diversity index) of the zooplankton community observed in the five sites of Silchar, Assam for the period of one month (July, 2014) consisting of 35 samples [(I): 6:00 am; (II): 9:00 am; (III): 12 noon; (IV): 3:00 pm; (V): 6:00 pm] for each time period of observations.LnS - natural logarithm of Species number, $\mathrm{LnE}$ - natural logarithm of Evenness value, and $\operatorname{Ln}(\mathrm{H})$ - natural logarithm of Shannon-Weiner diversity index. 


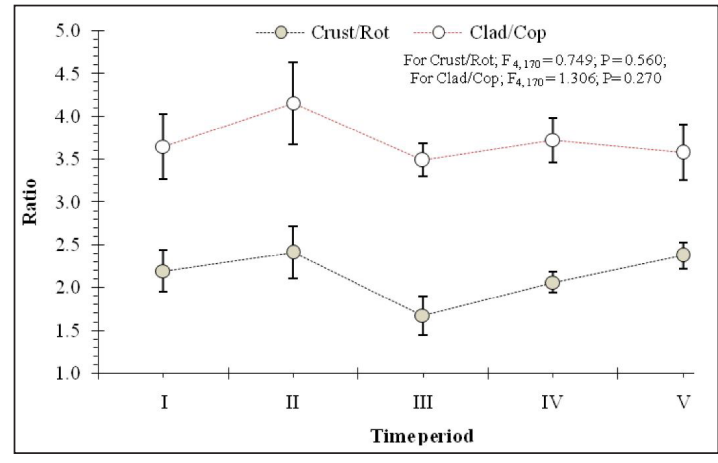

Figure 3. Ratio between crustacean and rotifer abundance (Crust/Rot) and between cladocerans and copepods (Clad/Cop) in the different time period in the day time observed in the wetlands of Silchar, Assam, India. The results of the ANOVA are also mentioned and the F-values are not significant. species composition in the different time periods. While the initial time periods (I and II) the dominance of the rotifers and the copepods was seen, the cladocerans were dominant in the later periods (III and IV) (Figure 5). The nodes representing cladocerans explained $30.86 \%$ of the data while the copepod explained $69.14 \%$ data as a split from the rotifer groups. Lower rotifer abundance and higher copepod abundance could explain the data of time periods of I, II and V (morning and evening time) while high rotifer and high cladoceran abundance could explain the data of time periods of III and IV (noon and afternoon time). The three groups of zooplankton, viz., Rotifera, Cladocera and Copepoda exhibited differential levels of abundance (Figure 6) and the

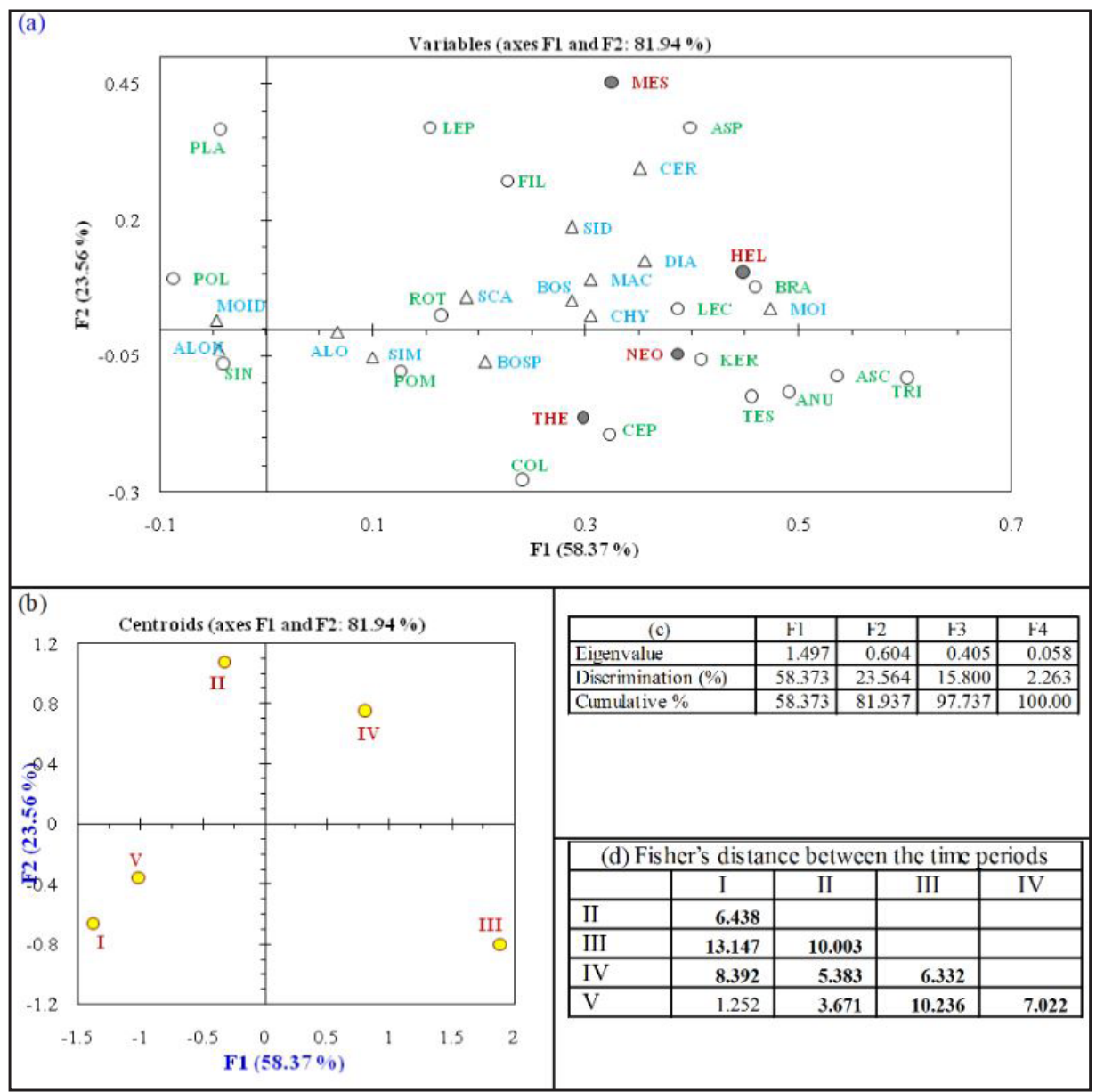

Figure 4. Biplot showing the ordination of the taxa of rotifers, cladocerans and the copepods used as the explanatory variables in the discriminant function analysis for justifying the differences of the five time periods viz., I (6:00am), II $(9: 00 \mathrm{am})$, III $(12 \mathrm{Noon})$, IV $(3: 00 \mathrm{pm})$, and V $(6: 00 \mathrm{pm})$. (a) The biplot representing the ordination of the 34 taxa of rotifers (open circles), claoderans (open triangle) and copepods (filled circles), as explanatory variables, (b) the biplot showing the ordination of the time periods in the day time used as response variable. The yellow circles represent the centroid of the response variables, (c) the eigenvalues and the discrimination attributable to the extracted factors, and (d) the Fisher's distance between the different time periods. The Wilks' lambda value was $0.168 ; \mathrm{F}_{56,613}=6.368 ; \mathrm{P}<0.001$, justifying the application of discriminant function analysis. The Fisher's distance in bold values are significant at $\mathrm{P}<0.001$ level. 


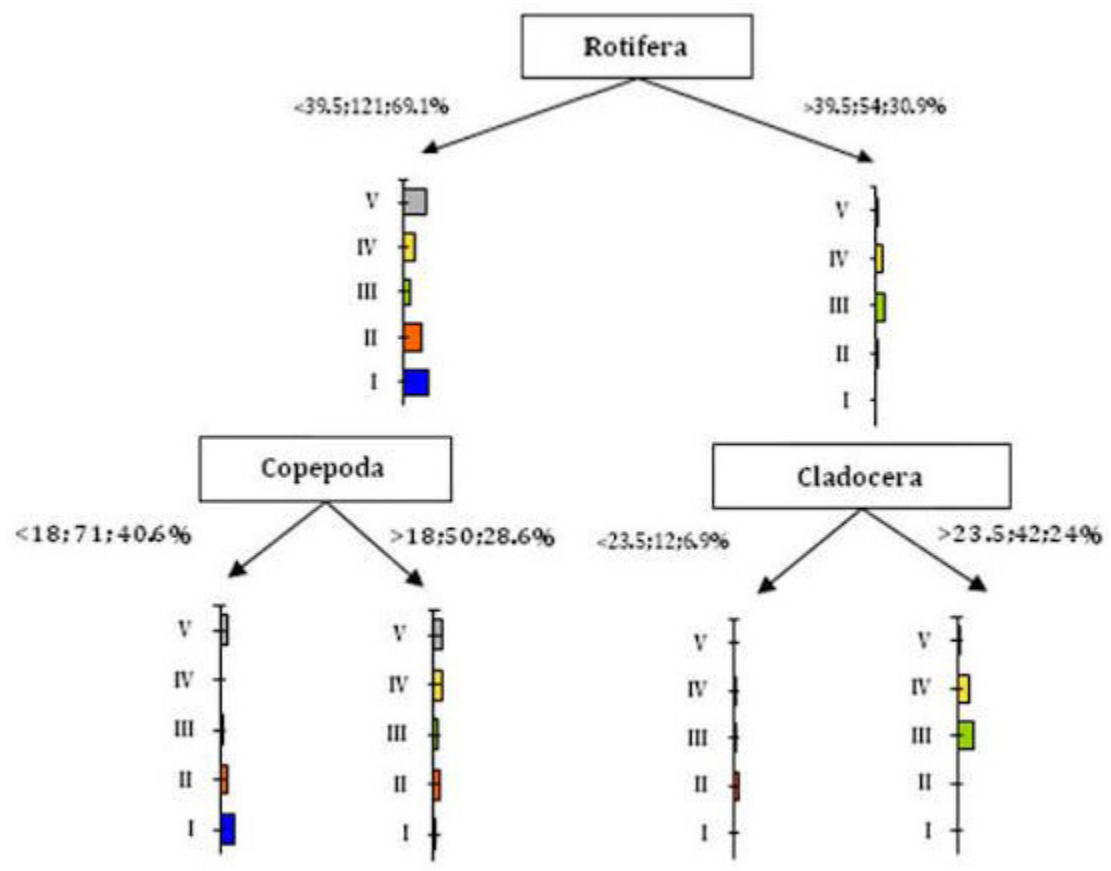

Figure 5. Regression tree showing the total abundance of the zooplankton in the five different time periods explained by the three groups, rotifers, cladocerans, and the copepods. At each node is the variable selected for the split and the threshold value for the composition of each groups. The relative frequency at each time period are shown in the bar diagrams in each of the splits. The numbers against each split represents the relative abundance followed by the number of observations and the \% variations explained.[(I): 6:00 am; (II): 9:00 am; (III): 12 noon; (IV): 3:00 pm; $(\mathrm{V}): 6: 00 \mathrm{pm}]$ The $\mathrm{P}$ values were significant at $\mathrm{P}<0.001$ level for each for the splits in cladoceran and copepod nodes.

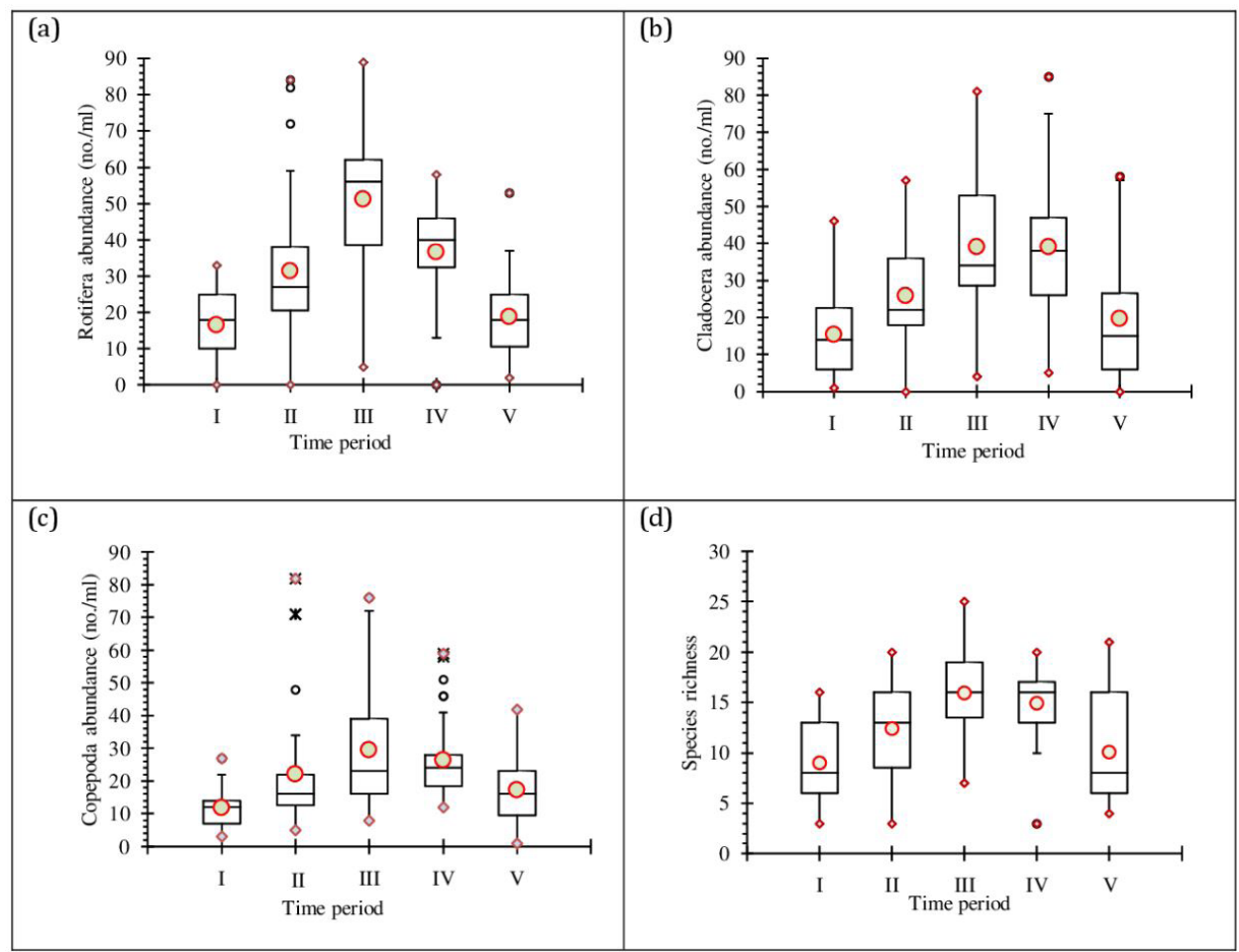

Figure 6. The box plot representation of the relative abundance of the three groups of zooplankton, (a)Rotifera, (b) Cladodera and (c) Copepoda, and total species richness (d) in the five different time period of a day. The mean values are shown in filled circles with the median values splitting the boxes and the extreme values and outliers are shown in different markers outside the box. Time periods, I (6:00am), II (9:00 am), III (12 Noon), IV (3:00pm), and $\mathrm{V}(6: 00 \mathrm{pm})$. 
Table 3. Parameters for identification of the time period and the sites as explanatory factors for the observed relative abundance of the Rotifera, Cladocera and Copepoda in the zooplankton species assemblages, following the equation: Abundance $=1 /\left(1+\exp \left(-\left(a+b_{1} x_{1}+b_{2} x_{2}\right)\right)\right)$, where $x_{1}$ is site and $x_{2}$ being the time period. The values in bold indicate significance at $\mathrm{P}<0.05$ level as per the Wald's Chi-square values and the logistic regression model.

\begin{tabular}{lccc}
\hline \multicolumn{1}{c}{ Zooplankton group } & Intercept $(\mathbf{a} \pm \mathbf{S E})$ & Site $\left(\mathbf{b}_{\mathbf{1}} \pm \mathbf{S E}\right)$ & Time period $\left(\mathbf{b}_{\mathbf{2}} \pm \mathbf{S E}\right)$ \\
\hline Rotifera & $0.2 \pm 0.06$ & $\mathbf{0 . 1 7} \pm 0.01$ & $\mathbf{0 . 0 6} \pm 0.02$ \\
Cladocera & $0.4 \pm 0.06$ & $\mathbf{0 . 0 9} \pm 0.01$ & $\mathbf{0 . 0 5} \pm 0.02$ \\
Copepoda & $2.04 \pm 0.07$ & $\mathbf{0 . 3 2} \pm 0.02$ & $0.014 \pm 0.02$ \\
Species richness & $-0.31 \pm 0.08$ & $-\mathbf{0 . 1 4} \pm 0.02$ & $\mathbf{0 . 0 6} \pm 0.02$ \\
Wald's chi square values for site and time period & & \\
Rotifera & & 171.96 & $\mathbf{1 4 . 0 0 3}$ \\
Cladocera & & $\mathbf{5 1 . 3 9 7}$ & $\mathbf{9 . 5 2 8}$ \\
Copepoda & & $\mathbf{4 7 8 . 8 1 7}$ & 0.735 \\
Species richness & & $\mathbf{5 1 . 9 2 0}$ & $\mathbf{9 . 7 8 5}$ \\
\hline
\end{tabular}

SE - Standard Error.

response of the groups varied with the sites and times. As observed through the GLM analysis (using logit link binomial functions) relative abundance of the Rotifera, Cladocera and Copepoda in the zooplankton species assemblages varied significantly with the sites and the time period in a day (Table 3). The results indicate that the relative contribution of the three groups towards time specific variations in the species composition and study sites as well as with time-scale of observation. Such variations reflected the dynamic nature of the species assemblages of the zooplankton in the concerned spaces within the wetlands.

\section{Discussion}

The results suggest that the species composition of the zooplankton varies with time in a day and is repeated daily, reflecting diel periodicity as observed in similar freshwater and marine ecosystems (Doulka \&Kehayias 2008). In the five different time periods in a day, the observations indicate that the species composition and the richness varies with the time period considerably, though the overall ratio of the three groups of the zooplankton remains same through the time period of observations. The species richness of the zooplankton varied considerably reaching to a peak during the noon and dwindling further with time (Burns \& Mitchell 1980). However, the abundance of the zooplankton including the ratio of the crustacean zooplankton and the rotifers remained similar though the species richness varied considerably over the time period. The diel variations in the species composition of the zooplankton reflect the rhythmic behavioural pattern guided by the environmental factors, like sunlight and temperature as well as the presence of the predators (Doulka \& Kehayias 2008;
Hansson et al., 2007). In the water bodies with higher depth, variation in the vertical scale is observed while for the shallow lakes of the tropical regions, variations in the horizontal scale are observed (Burks et al., 2002; Rabindranath et al., 2010). In both the instances, the role of the environmental factors including the presence of the predators is known to be crucial (George \& Fernando 1970). In parity with the patterns observed in the diel variations in the zooplankton species composition, the present study also observed variations in the species richness and the relative abundance of the species of the zooplankton observed in the five different time periods in the lakes and ponds of Assam, India. The observation on the species richness and the variations in the relative abundance of the different species (Table 2 and Figure 4) reflects ample heterogeneity in the species composition of the zooplankton in the water bodies (Sharma, 2011, 2014). The combinations of the rotifer and the copepod and the rotifer and the cladoceran remained significant at different time period in a day. However, the variations in the night time or during the darkness need to be judged further to understand the periodicity in the variations in the abundance of the different zooplankton species (Burns \& Mitchell, 1980; Dutta et al., 2009). Perhaps, the orientation of the zooplankton in space is related to the relative vulnerability to the predators or to the environmental factors that shape the community on the whole.

The movement of the zooplanktons results in changes in the species composition at a spatial scale. In general, the movements of the zooplankton follow either vertical or horizontal planes. Various factors account for the movements of the zooplankton including predation pressure, resource availability and the overall habitat quality (Jana, 1998). 
However, the determinants or the factors that govern the movement across the horizontal plane or the vertical plane vary with the size and depth of the lake. Thus the movements of the zooplankton realized as a diel periodicity differ between the large lake and small lakes or ponds. In large lakes where the vertical zonation is possible, the water quality including temperature and the nutrients form a vertical gradient, which in turn determines the movements of the zooplankton, particularly those that are vulnerable to predation (Miron et al., 2014). In case of shallow lakes, the movements tend to be horizontal, though the predation effects are more pronounced both in the littoral and the pelagic zones. Further, the shallow lakes have little or lack vertical gradient profound enough to execute movements for the fish and the predators along with the zooplankton species. Possibly, the light penetration and the corresponding movements of the phytoplankton are also a factor in driving the movements of zooplankton in the lakes and ponds in horizontal directions. Considering the movements of the zooplankton along the horizontal scale, the species composition are expected to vary, even at a particular space or site, assuming differences in the species specific preference of the space (Lauridsen et al., 1997). Assuming differences in the preferences of the microhabitat conditions and resources, the movements of zooplankton species are expected to vary, which would be reflected through the relative abundance at that instance (Arcifa et al., 2013). The relative number of species in the zooplankton assemblages varied with time. At the initial time period, the number of species observed was quite less than that of the subsequent time periods for the cladocerans and the rotifers, though the copepod species richness and abundance remained comparable over the time intervals. It may be assumed that multiple factors may have lead to the displacement of the species leading to the changes in the species composition.

Variation in the species composition of the zooplankton in shallow lakes and pond is common with reference to the time period of a day and in course of the seasons in a year. The changes within a short time period are reflection of the plankton movement within the habitat. The diel migration of the zooplankton implies that the interactions among the different groups and the predators vary with time in a day (Picapedra et al., 2015). Spatial occupancy as well as movements of the dependent groups varies according to the changes in the zooplankton species abundance (Lauridsen
\&Buenk, 1996). The response to the changing environmental conditions, particularly light availability and the changing turbid conditions of the freshwater bodies like lake and ponds are driving factors for the changes in the spatial occupancy of the zooplankton species (Lampert, 2005). Movement of the zooplankton within the space is also influenced by the presence of the vegetation that acts as a refuge to protect against the predators available in the same habitat (Wojtal et al., 2003). The studies on the diel migration and correlated responses of different groups of zooplankton portray the species specific adaptations to the changing environmental condition. The inference about the diel variations in the present instance was restricted to the major groups of zooplankton instead of assessing the species specific variations. Owing to the paucity of the information on the species specific interactions among the constituent members of the three different groups, the analysis was restricted to the higher taxonomic level. Still the less significant variations in the total copepods with respect to different time period within the day were obvious due to differential contribution of the species constituting the groups resulting in the invariant numbers all through the time period. This is relevant with reference to the predatory nature of the copepods that could thrive irrespective of the available species in the habitats. Further studies incorporating the physical factors and the biotic components that shape the zooplankton community organization may be studied to infer about the heterogeneity of the species composition during different time period in a day with higher precision.

\section{Conclusion}

In the freshwater lakes of Assam, India, the species composition of the zooplankton varied significantly with different time periods of a day. Although the pattern remained similar for the rotifers, cladocerans and copepods, the species richness of zooplankton varied significantly, supported by the diversity analysis. A correspondence of high and low abundances of rotifers and cladocerans was characteristic of the species composition of the zooplankton in the study area. The multivariate analysis using species as explanatory variables enabled classification of the different time periods in a day. The variations in the species composition in different time periods of a day suggest that the zooplankton exhibits movements either in horizontal or vertical directions induced by physical 
and/or biological factors. As a consequence, the combinations of zooplankton varied considerably, reflecting differential fitness values of the organisms. In conjunction with the studies on the diel periodicity of movements of zooplankton, the present study confirms the variations in the zooplankton species composition over time and being repeated following diel periodicity.

\section{Acknowledgements}

The authors are grateful to the respective Heads, Department of Zoology, Assam University, Silchar, Assam, and University of Calcutta, Kolkata, India for the facilities provided, including DST-FIST, Government of India. The authors, namely, Papia Das, Sulata Kar and Uma Das, acknowledge the financial assistance provided by UGC, India in carrying out the work.

\section{References}

ADDINSOFT. AddinsoftSarl. XLSTAT software, version 9.0.Paris: ADDINSOFT, 2010.

ALTINDAG, A., YIGIT, S. and ERGONOL, M.B.The zooplankton community of Lake Mogan, Turkey. Journal of Freshwater Ecology, 2007, 22(4), 709711. http://dx.doi.org/10.1080/02705060.2007.9 664832.

AMERICAN PUBLIC HEALTH ASSOCIATION - APHA. Standard methods for the examination of water and wastewater. 20th ed. Washington: APHA/ AWWA, 2005.

ARCIFA, M.S., BUNIOTO, T.C., PERTICARRARI, A. and MINTO, W. J. Diel horizontal distribution of microcrustaceans and predators throughout a year in a shallow neotropical lake.Brazilian Journal of Biology = RevistaBrasileira de Biologia, 2013, 73(1), 103-114. http://dx.doi.org/10.1590/S151969842013000100012. PMid:23644793.

BATTISH, S. K. Freshwater Zooplankton of India.New Delhi: Oxford \& IBH Publishing Co. Pvt. Ltd, 1992.

BRAGHIN, L.D.S.M., SIMÓES, N.R. and BONECKER, C.C. Hierarchical effects of local factors on zooplankton species diversity.Inland Waters, 2016, 6(4), 645-654. http://dx.doi.org/10.1080/IW6.4.919.

BURKS, R.L., LODGE, D.M., JEPPESEN, E. and LAURIDSEN, T.L. Diel horizontal migration of zooplankton: costs and benefits of inhabiting the littoral.Freshwater Biology, 2002, 47(3), 343-365. http://dx.doi.org/10.1046/j.13652427.2002.00824.x.

BURNS, C.W. and MITCHELL, S.F. Seasonal succession and vertical distribution of zooplankton in Lake Hayes and Lake Johnson. New Zealand Journal of Marine and Freshwater Research, 1980, 14(2),
189-204. http://dx.doi.org/10.1080/00288330.19 80.9515860 .

DE'ATH, G. and FABRICIUS, K.E. Classification and regression trees: A powerful yet simple technique for ecological data analysis.Ecology, 2000, 81(11), 3178-3192. http://dx.doi.org/10.1890/00129658(2000)081[3178:CARTAP]2.0.CO;2.

DOULKA, E. and KEHAYIAS, G. Spatial and temporal distribution of zooplankton in Lake Trichonis, Greece. Journal of Natural History, 2008, 42(5-8), 575-595. http://dx.doi.org/10.1080/00222930701835555.

DUTTA, T.K., PAHARI, P.R. and BHATTACHARYA, T. Diel variation and the effect of starvation on Amylase activity of Heliodiaptomus cinctus (Gurney), (Crustacea: Copepoda: Calanoida).Biological Rhythm Research, 2009, 40(3), 249-255. http://dx.doi. org/10.1080/09291010802402196.

EDMONDSON, W.T. Freshwater biology. 2nd ed. New York: John Wiley \& Sons, 1959.

EVANS, J.H. Spatial and seasonal succession and vertical distribution of phytoplankton in an African rift valley lake (L. Albert, Uganda, Zaire). Hydrobiologia, 1997, 354(1/3), 1-16. http://dx.doi. org/10.1023/A:1003026415788.

GEORGE, D.G. and HEANEY, S.I. Factors influencing the spatial distribution of phytoplankton in a small productive lake.Journal of Ecology, 1978, 66(1), 133155. http://dx.doi.org/10.2307/2259185.

GEORGE, M.G. and FERNANDO, C.H. Diurnal migration in three species of rotifers in sunfish lake, Ontario.Limnology and Oceanography, 1970, 15(2), 218-223. http://dx.doi.org/10.4319/ lo.1970.15.2.0218.

HANSSON, L.-A., BECARES, E., FERNÁNDEZALÁEZ, M., FERNÁNDEZ-ALÁEZ, C., KAIRESALO, T., ROSA MIRACLE, M., ROMO, S., STEPHEN, D., VAKKILAINEN, K., VAN DE BUND, W., VAN DONK, E., BALAYLA, D. and MOSS, B. Relaxed circadian rhythm in zooplankton along a latitudinal gradient.Oikos, 2007, 116(4), 585-591. http://dx.doi.org/10.1111/j.00301299.2007.15754.x.

HAYS, G.C. A review of the adaptive significance and ecosystem consequences of zooplankton diel vertical migrations. Hydrobiologia, 2003, 503(1-3), 163-170. http://dx.doi.org/10.1023/ B:HYDR.0000008476.23617.b0.

JANA, B.B. State-of-the-art of lakes in India: an overview. Archiv für Hydrobiologie, 1998, 121, 1-89. Supplement.

LAMPERT, W. Vertical distribution of zooplankton: density dependence and evidence and evidence for an ideal free distribution with costs.BMC Biology, 2005, 10, 3-10. PMid:15813974.

LAURIDSEN, T.L. and BUENK, I. Diel changes in the horizontal distribution of zooplankton in two 
shallow eutrophic lakes.Archiv für Hydrobiologie, 1996, 137, 161-176.

LAURIDSEN, T.L., JEPPESEN, E., SONDERGAARD, M. and LODGE, D.M. Horizontal migration of zooplankton: predator-mediated use of macrophyte habitat. In: E. M.JEPPESEN, M.SONDERGAARD, M.SONDERGAARD\&K.CHRISTOFFERSEN, eds. The structuring role of submerged macrophytes in lakes. New York: Springer Verlag, 1997. pp. 233-239. Ecological Studies, vol. 131.

LEGENDRE, P. and LEGENDRE, L. Numericalecology. 2nd ed. The Netherlands: Elsevier, 1998.

MACK, H.R., CONROY, J.D., BLOCKSOM, K.A., STEIN, R.A. and LUDSIN, S.A. A comparative analysis of zooplankton field collection and sample enumeration methods.Limnology and Oceanography, Methods, 2012, 10(1), 41-53. http://dx.doi. org/10.4319/lom.2012.10.41.

MANLY, B.F.J. Multivariate statistical methods: a primer. London, UK: Chapman and Hall, 1994.

MICHAEL, R.G. and SHARMA, B.K. Indian Cladocera (Crustacea: Branchiopoda: Cladocera).Kolkata: Zoological Survey of India, 1988. Fauna of India and adjacent countries series.

MIRON, M.I.B.D., CASTELLANOS-PÁEZ, M.E., GARZA-MOURIÑO, G., FERRARAGUERRERO, M.J. and PAGANO, M. Spatiotemporal variations of zooplankton community in a shallow tropical brackish lagoon (Sontecomapan, Veracruz, Mexico).Zoological Studies (Taipei, Taiwan), 2014, 53, 59.

NASH, R.A. A relationship between screen opening and mesh size for standard sieves.Pharmaceutical Development and Technology, 1997, 2(2), 185-186. http://dx.doi.org/10.3109/10837459709022624. PMid:9552445.

PANSERA, M., GRANATA, A., GUGLIELMO, L., MINUTOLI, R., ZAGAMI, G. and BRUGNANO, C. How does mesh mesh-size selection reshape the description of zooplankton community structure in coastal lakes?Estuarine, Coastal and Shelf Science, 2014, 151, 221-235. http://dx.doi.org/10.1016/j. ecss.2014.10.015.

PEPIN, P., JOHNSON, C.L., HARVEY, M., CASAULT, B., CHASSE, J., COLBOURNE, E.B., GALBRAITH, P.S., HEBERT, D., LAZIN, G., MAILlET, G., PLOURDE, S. and STARR, M. A multivariate evaluation of environmental effects on zooplankton community structure in the Western North Atlantic.Progress in Oceanography, 2015, 134, 197-220. http://dx.doi.org/10.1016/j. pocean.2015.01.017.

PERTICARRARI, A., ARCIFA, M.S. and RODRIGUEZ, R.A. Diel vertical migration of cladocerans in a tropical lake.Nauplius, 2003, 11(1), 15-25.

PICAPEDRA, P.H.S., LANSAC-TOHA, F.A. and BIALETZKI, A. Diel vertical migration and spatial overlap between fish larvae and zooplankton in two tropical, Brazil. Brazilian Journal of Biology = RevistaBrasileira de Biologia, 2015, 75(2), 352-361. http://dx.doi.org/10.1590/1519-6984.13213. PMid:26132018.

RABINDRANATH, A., DAASE, M., FALKPETERSEN, S., WOLD, A., WALLACE, M.I., BERGE, J. and BRIERLEY, A.S. Seasonal and diel vertical migration of zooplankton in the High Arctic during the autumn midnight sun of 2008.Marine Biodiversity, 2010, 41(3), 365-382. http://dx.doi. org/10.1007/s12526-010-0067-7.

RICCARDI, N. Selectivity of plankton nets over mesozooplankton taxa: implications for abundance, biomass and diversity estimation.Journal of Limnology, 2010, 69(2), 287-296. http://dx.doi.org/10.4081/ jlimnol.2010.287.

SHARMA, A.S., GUPTA, S. and SINGH, N.R. Zooplankton community of Keibul Lamjao National Park (KLNP) Manipur, India in relation to the physico-chemical variables of the water. Chinese Journal of Oceanology and Limnology, 2017, 35(3), 469-480. http://dx.doi.org/10.1007/s00343-017-5341-0.

SHARMA, B.K. Rotifers (Rotifera: Eurotatoria) from wetlands of Majuli - the largest river island, the Brahmaputra river basin of upper Assam, northeast India.Check List, 2014, 10(2), 292-298. http://dx.doi. org/10.15560/10.2.292.

SHARMA, B.K. Zooplankton communities of Deepor Beel (a Ramsar site), Assam (N. E. India): ecology, richness, and abundance. Tropical Ecology, 2011, 52(3), 293-302.

SHARMA, S. and SHARMA, B.K. Zooplankton diversity in floodplain lakes of Assam. Records of Zoological Survey of India. Kolkata: The Director, Zoological Survey of India, 2008, pp. 1-307. Occasional paper, no 290.

SIEGFRIED, C., AUER, N.A. and EFFLER, S.W. Changes in the zooplankton of Onondaga Lake: Causes of implications.Lake and Reservoir Management, 1996, 12(1), 59-71. http://dx.doi. org/10.1080/07438149609353997.

WOJTAL, A., FRANKIEWICZ, P., IZYDORCZYK, K. and ZALEWSKI, M. Horizontal migration of zooplankton in a littoral zone of the lowland Sulejow Reservoir (Central Poland).Hydrobiologia, 2003, 506-509(1-3), 339-346. http://dx.doi.org/10.1023/ B:HYDR.0000008627.55462.e1.

ZAR, J.H. Biostatistical analysis.4th ed. New Delhi, India: Pearson Education Singapore Pte. Ltd, 1999.

Received: 25 February 2018 Accepted: 13 April 2020

Associate Editors:Antonio Fernando Monteiro Camargo, Irineu Bianchini Junior. 